\title{
DE LA DICTADURA A LA REPÚBLICA: ORÍGENES Y AUGE DE LOS MOVIMIENTOS JUVENILES EN ESPAÑA ${ }^{1}$
}

\author{
EDUARDo GONZÁlEZ CALlEJA y SANDRA SOUTO KuSTRÍN \\ Universidad Carlos III e Instituto de Historia del CSIC (España)
}

RESUMEN: Este artículo analiza el proceso de surgimiento y consolidación de las organizaciones juveniles en España que las convirtió en organismos prácticamente autónomos de sus referentes adultos. Se estudian las condiciones que favorecieron este proceso, la evolución de las principales organizaciones juveniles, sus relaciones con las organizaciones e instituciones politicas de "los adultos» y su papel en la conflictividad social y politica. Se parte de las primeras protestas estudiantiles y de la formación de las primeras secciones juveniles de partido para, a continuación, estudiar el desarrollo de la protesta estudiantil durante la dictadura de Primo de Rivera y la década de auge de los movimientos juveniles que supuso el periodo comprendido entre 1931 y 1939.

Palabras Clave: España. Organizaciones juveniles. Movilización política. Periodo de entreguerras.

ABSTRACT: This article analyses the rise and consolidation of youth organisations in Spain, which made them almost autonomous bodies in relation to their parent organisations. The article examines the conditions which favoured this process, the development of the major youth organisations, their relationship with political organisations and entities, and the role of young people in the social and political conflicts which took place in Spain during the 1920s and 1930s. The work begins by analysing the first student protests and the shaping of the first party youth sections, continuing with a study of the development of student protest during Primo de Rivera's Dictatorship, and the decade of the boom in youth movements in the period between 1931 and 1939.

KEY WORDS: Spain. Youth organisations. Political mobilisation. Interwar period.

1 Este artículo se ha realizado en el marco del proyecto de investigación «Grupos profesionales, corporativismo y políticas sectoriales del Estado durante la Dictadura de Primo de Rivera, 19231930» (HUM 2004-00406/HIST). 


\section{INTRODUCCIÓN}

El fenómeno de la movilización juvenil, aunque muy poco estudiado por la historiografía, tiene una larga historia en nuestro país. Pero el retraso de España con respecto a otros países del continente europeo en la modernización socioeconómica y en el establecimiento de un sistema democrático, también tuvo su correlato en un retraso en el desarrollo no sólo de las organizaciones específicamente juveniles sino también de las políticas de los gobiernos hacia ellas: mientras que en 1891 en Alemania se prohibió el trabajo a los menores de 14 años, recién en 1900 se aprobó en España una ley que prohibía el trabajo a los menores de 10 años ${ }^{2}$.

Como sucede en otros países europeos, los primeros movimientos de protesta juvenil fueron fundamentalmente universitarios. Hasta comienzos del siglo XX no surgieron las primeras formaciones juveniles vinculadas a los distintos partidos y organizaciones políticas y con vocación de perdurabilidad, especialmente en las regiones más avanzadas económica y socialmente como, por ejemplo, Cataluña. Pero es desde finales de los años veinte cuando se puede hablar de organizaciones juveniles propiamente dichas, ya que hasta entonces eran meros instrumentos de las organizaciones políticas a las que pertenecían. En general, las entidades juveniles carecieron hasta los años de la Segunda República de un programa de reivindicaciones y objetivos específicamente juveniles $^{3}$. Los jóvenes, principalmente los estudiantes, jugaron un papel importante en la caída de la dictadura de Primo de Rivera. La llegada de la Segunda República, con su correlato de modernización social y democratización política, impulsó el desarrollo de nuevas organizaciones de masas y la movilización social y política general, y las organizaciones juveniles y la movilización juvenil en concreto. Finalmente, los jóvenes jugarían un papel importante en la guerra civil, ocupando puestos de mando político y militar muy importantes, especialmente en la zona republicana, dado que la organización más jerárquica y militar del poder en el bando franquista, lo hacía más difícil, aunque no imposible.

Para poder reflejar la complejidad y variedad de esta movilización de los sectores más jóvenes de la sociedad española y las condiciones que la facilitaron y que la explican, vamos a iniciar este artículo con un breve análisis de las primeras movilizaciones juveniles que se produjeron en nuestro país desde la segunda mitad del siglo XIX, y la formación de las primeras organizaciones juveniles políticas en las primeras décadas del siglo XX, para centrarnos después

2 Mitterauer, Michael: A History of Youth, Oxford, 1992, pp. 86-87; Martín Valverde, Antonio et alii: La legislación social en la Historia de España. De la revolución liberal a 1936, Madrid, 1987, pp. 65-66.

3 Ver SAMPer I TRIeDU, Genís: La Joventut fa Catalunya. 1900-1985. Aproximació a la història de les associacions de Joves, Barcelona, 1987, pp. $30-36$ (cronología de la formación de las organizaciones juveniles de Cataluña), y GÓMEZ MOLLEDA, Dolores: «Juventud y Política en la España Contemporánea», en Studia Historica. Historia Contemporánea (Salamanca), vol. V, no 4 (1987), pp. 7-20, p. 9. 
en los tres momentos (dictadura de Primo de Rivera, Segunda República y guerra civil) que marcan los hitos de esta transformación de la acción política de la juventud en España.

\section{LAS PRIMERAS MOVILIZACIONES JUVENILES}

Las primeras grandes movilizaciones universitarias se remontan en España a la segunda mitad del siglo XIX. Este fue el caso de la «Noche de San Daniel» de 10 de abril de 1865 , vinculada a la defensa de la libertad de cátedra y que fue el preludio de acciones revolucionarias más serias, como la rebelión del cuartel de San Gil de 22 de junio de 1866, durante la cual grupos de estudiantes salieron a la calle y erigieron barricadas, en un atisbo de movilización juvenil en apoyo de una iniciativa castrense de carácter progresista que se repetiría en otras ocasiones. Los alborotos de la «Santa Isabel», acaecidos del 17 al 22 de noviembre de 1884, tuvieron también un móvil ideológico y académico, en el que las críticas al apoyo que la Monarquía restauracionista brindaba al clero católico se integraban en un debate más amplio sobre las relaciones entre libertad de cátedra y respeto al dogma religioso ${ }^{4}$. Pero, como dice Cepeda Adán, si por una parte, la protesta estudiantil tenía un difícil tratamiento por las fuerzas en el poder, porque el estudiante pertenecía «casi en exclusiva a los estamentos pudientes de la sociedad, especialmente a la burguesía [...] que, al enfrentarse con la protesta 'de sus hijos', reacciona con menos dureza que contra otras fuerzas de oposición», a la vez, el carácter temporal de la permanencia en la universidad, hacía incapaz al estudiantado de mantener proyectos asociativos duraderos. Esto también favorecía la falta de coordinación entre las protestas estudiantiles y otros movimientos sociales, lo que hacía menos peligrosa la movilización estudiantils.

Con el malestar cultural y la incertidumbre política y económica ligados al cambio de siglo, los desórdenes estudiantiles aumentaron, y con ellos la atención dada a este tipo de acciones reivindicativas por los gobiernos. El primer lustro del siglo XX presenció un recrudecimiento de la conflictividad estudiantil, vinculado a la definición de un modelo renovado de enseñanza pública, pero también a la agudización de los enfrentamientos ideológicos anejos al proceso secularizador y a la emergencia de corrientes políticas contestatarias como el catalanismo o un republicanismo renovado. El 27 de noviembre de 1902, los universitarios barceloneses se enfrentaron con la policía en protesta contra un decreto del ministro de Instrucción Pública que limitaba las posibilidades de

4 Sobre estas primeras movilizaciones juveniles, véanse RUPÉREZ, Paloma: La cuestión universitaria y la noche de San Daniel, Madrid, 1975; y MORAYTA, Miguel: La libertad de cátedra. Sucesos universitarios de la Santa Isabel, Madrid, 1911. Una revisión reciente de estas agitaciones escolares, situadas en perspectiva transecular, en GONZÁlez CALLEJA, Eduardo: «Rebelión en las aulas: un siglo de movilizaciones estudiantiles (1865-1969)», en Ayer (Madrid), n 59, 2005 (3), pp. 21-49.

5 Cepeda Adán, José: Los movimientos estudiantiles, Madrid, 1985, pp. 6-7, la cita en p. 6. 
enseñanza del Catecismo en catalán. En las primaveras de 1903 y 1905 se produjeron conflictos estudiantiles en distintas universidades, vinculados a la emergencia de un movimiento universitario republicano definido contra la presencia abusiva del clericalismo en las aulas. La protesta estudiantil fue, pues, un hecho muy frecuente en los primeros años del siglo XX, pero en raras ocasiones alcanzó la consistencia y la perdurabilidad necesarias para desencadenar una crisis política de envergadura.

Tras la crisis de 1898 los nuevos movimientos políticos surgidos en el ámbito urbano, como el socialismo, el republicanismo radical o la variante jaimista del legitimismo carlista, alentaron el encuadramiento juvenil como una actividad sectorial imprescindible para llevar adelante una actividad pública diferente de la oligárquica al uso entre los partidos del «turno». Las primeras organizaciones políticas juveniles surgieron a lo largo de los primeros años del siglo $\mathrm{XX}$, generando no pocas tensiones con los grupos dirigentes de sus respectivos partidos. En septiembre de 1903 se creó la primera sección juvenil socialista en Bilbao, por iniciativa de los jóvenes vascos frente a la «reticencia y recelo» de los dirigentes del partido, que no veían la necesidad de una organización juvenil independiente. En 1906 la Federación de Juventudes Socialistas de España (FJS) celebró su primer congreso nacional. Aunque teóricamente autónoma del partido, de hecho estaba muy condicionada por las directrices de éste, como se refleja en la expresión «organismo auxiliar» que el PSOE utilizaba para referirse a ella. Así, durante los primeros años de su existencia, su actividad se centró en la realización de actividades educativas y en la colaboración con el partido en las campañas de propaganda. Su campo de acción particular fue la lucha antimilitarista que, adaptada a la situación española, suponía la lucha por la democratización de las levas ${ }^{6}$. Su crecimiento fue lento y con altibajos: en 1906, contaba con 1.109 federados, éstos habían bajado a 1.070 en 1908 , pero pasaron a 2.433 en 1912, lo que puede reflejar la concienciación juvenil ante la guerra de Marruecos. La conjugación de los conflictos en Marruecos con la Primera Guerra Mundial permitió un importante ascenso de la organización juvenil socialista, que alcanzó los 6.138 afiliados en $1915^{7}$.

6 Desde 1912 se permitió la reducción del servicio militar mediante el pago de una cantidad (cuota), que permitía también elegir arma, cuerpo y unidad militar. Obviamente, esto creaba desigualdades porque el sistema de cuota sólo era accesible para aquellos jóvenes cuyos padres contaban con cierto nivel económico.

7 Véase GONZÁLEZ QuiNTANA, Antonio: «La primera organización de jóvenes proletarios españoles: las Juventudes Socialistas de España o el fracaso de una alternativa juvenil de clase (19031921)», en Studia Historica. Historia Contemporánea (Salamanca), vol. 5, nº. 4, (1987), pp. 21-46, pp. 22-32. Los datos de afiliados los daba la FJS en Renovación, órgano de la Federación Nacional de Juventudes Socialistas, octubre de 1915, Número extraordinario dedicado al Congreso de Juventudes, p. 7. Sobre la actividad pedagógica de la FJS se puede ver también De LuIS MARTín, Francisco: «Las Juventudes Socialistas como frente cultural pedagógico del socialismo español: el caso madrileño, 1903-1914», en De Luis Martín, Francisco: Cincuenta años de cultura obrera en España, 18901940, Madrid, 1994, pp. 263-282. 
Pero quizás la organización juvenil que alcanzó mayor importancia en los primeros años del siglo XX fue la de los «jóvenes bárbaros» surgidos a partir de 1904 en el seno de la Juventud Republicana de Barcelona afín al líder radical Alejandro Lerroux. Su época dorada se produjo entre 1906 y 1909, sobre todo en torno al triunfo electoral de Solidaritat Catalana. La Agrupación de Jóvenes Bárbaros, creada en 1911-12, intentó actuar como una corriente autónoma y anarquizante en el seno de la Federación de Juventudes Radicales, hasta que se produjo su declive en 1915, en parte debido a que desde fines de 1912 se había constituido en el seno del Partido Radical una Federación de Juventudes Radicales como medio de contención de los impulsos revolucionarios de sus militantes menos maduros 8 .

Es significativo también que fuera en este momento (1912) cuando surgieran en España los Boy Scouts, con el placet del rey Alfonso XIII. Fueron reconocidos por Real Orden de febrero de 1914 como Asociación de Exploradores de España. Pero dicha asociación, a pesar de tener los mismos objetivos de control de la juventud que su modelo británico - así, en el artículo primero de sus estatutos se recogía que su objetivo era "desarrollar en la juventud el amor a la Patria, el respeto al Jefe del Estado y a las Leyes de la Nación, el culto al Honor»- no lograría el éxito del movimiento escultista británico, y se mantendrían como una organización bastante marginal, entrando en una crisis definitiva durante la guerra civil ${ }^{9}$.

En el período que transcurre entre 1912 y 1916 comenzaron a surgir en España las primeras manifestaciones de un fenómeno nuevo, que alcanzaría magnitud continental durante el período de la «paz armada»: la radicalización ideológica y la movilización de ciertos sectores conservadores que prefiguraban la gran agitación antirrevolucionaria de la primera posguerra mundial. En España, los sectores sociales más identificados con esta «nueva derecha» no gozaron de gran autonomía, sino que aparecieron encuadrados dentro de movimientos políticos menos extremistas. Este fue el caso del carlismo y del maurismo, exponentes primigenios de esta radicalización antirrevolucionaria de las juventudes que alcanzaría larga fortuna en la década siguiente. En los primeros años del siglo aparecieron en Madrid (1902) y Barcelona (1903) los primeros «Batallones de la Juventud» carlistas que efectuaban marchas intimida-

8 Sobre los «jóvenes bárbaros», véase CULLA Y CLARÀ, Joan B.: El republicanisme lerrouxista a Catalunya (1901-1923), Barcelona, 1986, pp. 139-155 y «Ni tan jóvenes, ni tan bárbaros. Las juventudes en el republicanismo lerrouxista barcelonés», en Ayer (Madrid), no 59, 2005 (3), pp. 51 67. Su predisposición violenta, en GonZález CALleja, Eduardo: La razón de la fuerza. Orden público, subversión y violencia política en la España de la Restauración (1875-1917), Madrid, 1998, pp. 381-389.

9 SÁEZ MARÍN, Juan: «Asociacionismo juvenil en España hasta 1936-39», en De Juventud (Madrid), $\mathrm{n}^{\circ} 7$ (1988), pp. 37-57, pp. 39-40, la cita es de esta última página. La Asociación de Exploradores de España decía contar a finales de 1914 con 18.024 miembros y entre sus vocales se encontraba Miguel Primo de Rivera. Sobre los scouts británicos ver SpRINGHALl, John O.: Youth, Empire and Society. British Youth Movements, 1883-1940, Londres-Hamden (Conn.), 1977. 
torias en el centro de las ciudades. En 1907 se fundó el Requeté como rama activista de los carlistas de menor edad, aunque se distinguía un Requeté «civil» infantil y otro militarizado juvenil, nutrido por militantes aún más jóvenes que los de los «Batallones de la Juventud», con los que convivieron de forma bastante estrecha hasta finales de la década. Algunos sectores de la juventud jaimista y de su milicia aneja se fueron alejando del tradicionalismo oficial para ensayar actitudes populistas y obreristas más extremas. Estos jóvenes jaimistas intransigentes, reunidos en torno a publicaciones como El Cañón o La Trinchera, estaban muy lejos de aceptar el papel impuesto al Requeté como «grupo de orden» del conservadurismo político o social. Pero los jóvenes jaimistas radicales catalanes no lograron articular un proyecto contrarrevolucionario mínimamente coherente, que les situase a la altura de la «derecha revolucionaria» europea más evolucionada, con la que pretendían homologarse ${ }^{10}$.

Los jóvenes mauristas constituyeron el sector más bullicioso del conservadurismo disidente, y el más identificado con un proyecto de revisión autoritaria y personalista del sistema parlamentario. El movimiento maurista celebró una primera Asamblea Nacional los días 20 y 21 de enero de 1914, organizada por una nutrida representación de la Juventud conservadora. El mito de la «revolución desde arriba», las referencias a la virilidad o los llamamientos a la rebeldía política y generacional (elemento retórico también presente en el acervo subcultural del lerrouxismo), mitigados por los alegatos a favor del cumplimiento responsable de los «deberes de ciudadanía», formaron parte fundamental del discurso de los jóvenes mauristas, cuyos elementos más extremistas mostraron fuertes dosis de autonomía respecto a los sectores más burocratizados del propio movimiento. Los primeros meses de 1914 fueron los de más intensa actividad del «maurismo callejero», cuyos miembros más jóvenes, inspirados en los expeditivos métodos de actuación de grupos reaccionarios como los «Camelots du Roi» de l'Action Française (federados a partir de 1910), crearon a mediados de junio una Federación Nacional de Juventudes Mauristas, para lograr la coordinación del movimiento en el ámbito estatal. Esta Federación Nacional se constituyó de forma efectiva en una asamblea celebrada en Madrid en abril de 1915, que eligió una junta directiva de marcado carácter centralista, presidida por Antonio Goicoechea. Nutridos por hijos de la aristocracia y de la clase media acomodada, los «jóvenes mauristas» consideraban caduco el orden de la Restauración y se proponían regenerar el sistema a base de una política de «orden y ciudadanía». Aunque el «maurismo callejero» recurrió a modernos mecanismos de propaganda masiva que no excluían la confrontación callejera, sus

10 Sobre esta incipiente organización paramilitar juvenil, véanse ARÓsTEGUI, Julio: «La tradición militar del carlismo y el origen del Requeté», en Aportes (Madrid), no 8 (6/1988), pp. 3-23; GONZÁLEZ CALLEJA, Eduardo: «Paramilitarització i violència política a l'Espanya del primer terç de segle: el requetè tradicionalista (1900-1936)», en Revista de Girona (Gerona), no 147 (julio 199), pp. 69-76 y La razón de la fuerza..., op. cit., pp. 477-504; y WinstOn, Colin M.: Workers and the Right in Spain, 1900-1936, Princeton, 1985, pp. 76-88. 
esfuerzos movilizadores quedaron frustrados cuando la campaña «pro Maura» hubo de ser abruptamente clausurada con el estallido de la Primera Guerra Mundial. Tras los fracasos de los sucesivos gobiernos presididos por Maura en marzo-noviembre de 1918, abril-julio de 1919 y agosto de 1921 a marzo de 1922, su movimiento político se sumió en una dinámica irreversible de fraccionamiento que se consumó en 1922 con la aparición de una tendencia ortodoxa caracterizada por su fidelidad al declinante caudillo, otra democristiana representada por el Partido Social Popular de Ángel Ossorio, y una tercera autoritaria reunida en torno al periódico La Acción, que prolongaría sus actividades hasta la década de los treinta y en la que los elementos más extremistas de las juventudes mauristas tuvieron un papel decisivo ${ }^{11}$.

La incorporación de los jóvenes a la anarcosindicalista Confederación Nacional del Trabajo (CNT), creada en 1910, se anticipó muchos años a la creación de una organización juvenil anarquista, lo que no sucedería hasta la Segunda República. Como indica Chris Ealham, en una de las ciudades más desarrolladas de España y «feudo» confederal como Barcelona, los «pánicos morales» de la burguesía guardaban mucha relación con el incremento del número de jóvenes obreros, acostumbrados a relacionarse en las calles, lo que no hacían los jóvenes de la clase media, y que continuamente tenían problemas con las fuerzas de orden público y eran considerados adolescentes «agresivos» e «insolentes» (según ciertos prejuicios, «en la calle sólo juegan los golfos»). Se temía que estos jóvenes callejeros «incontrolados» se aliaran con el movimiento revolucionario y, según diferentes testimonios recopilados por Ealham, muchas de las pandillas callejeras de obreros jóvenes estaban en la órbita de los sindicatos de la CNT. Las secciones juveniles de los Ateneos Libertarios contribuyeron a evitar la división generacional, estableciendo relaciones duraderas de amistad entre jóvenes y adultos. En 1920, los miembros más importantes del grupo de acción «Los Solidarios» eran varones solteros de 19 a 25 años de edad, con trabajos no cualificados y eventuales. Pero a pesar de la presencia continuada de jóvenes en el movimiento anarcosindicalista, ésta no fue acompañada de un discurso referido a la juventud, como un grupo específico, con objetivos, problemas y características propias, hasta la Segunda República ${ }^{12}$.

El eco de la Gran Guerra no sólo propició la movilización contrarrevolucionaria de las formaciones juveniles de derecha. El triunfo de la revolución en Rusia condujo a una evidente polarización de posturas en el socialismo español

11 Sobre los rasgos juveniles del «maurismo callejero» resultan interesantes las memorias de GutIÉRREZ-RAvÉ, José: Yo fui un joven maurista (Historia de un movimiento de ciudadanía), Madrid, s.f. Ver también GonZÁlez CALlejA, Eduardo: La razón de la fuerza, op. cit., pp. 504-515.

12 Las citas son de BALlester, J.: Memòries d'un noi de Gràcia, Barcelona, 1999, p. 52, cit. por EALHAM, Chris: La lucha por Barcelona. Clase, cultura y conflicto, 1898-1937, Madrid, 2005, p. 47. Para lo demás, ver este último libro citado, pp. 51, 76 y 91 y ss.; y TAVERA, Susanna: «Escola de Rebel.lia. La joventut i l'anarcosindicalisme», en UCELAY DA CAL, Enric (dir.): La joventut a Catalunya al segle XX. Materiales per a una historia, Barcelona, 1987, vol. 1, pp. 138-151. 
que tuvo mucho de ruptura generacional. La Federación de Juventudes Socialistas fue la punta de lanza de la tendencia pro-bolchevique en el seno del PSOE. En su congreso de diciembre de 1919, la FJS decidió adherirse a la Tercera Internacional, y en abril de 1920 los jóvenes socialistas — los llamados «cien niños»— formaron el Partido Comunista Español. La reconstruida FJS languidecería a partir de ese momento hasta los años treinta. En 1921, tenía 3.424 afiliados y la política del PSOE de colaboración con la dictadura de Primo de Rivera, que dividió a la organización juvenil entre partidarios y detractores de dicha estrategia, no favorecería su desarrollo: en diciembre de 1929 sus militantes eran 2.697. Sin embargo, el PCE sería sólo una fuerza meramente testimonial hasta los años treinta y su organización juvenil, la Unión de Juventudes Comunistas de España (UJCE), creada en 1922, no pasó de unos centenares de afiliados durante la dictadura de Primo de Rivera ${ }^{13}$.

$\mathrm{La}$ «primavera de los pueblos» patrocinada por el discurso emancipador del presidente estadounidense W. Wilson se reflejó en un intenso rearme activista de las juventudes vinculadas a los partidos nacionalistas. La Juventud Vasca de Bilbao, fundada por Elías Gallastegui el 14 de febrero de 1904, se hizo con el control de la Federación de Juventudes Vascas en 1919. La intensificación de sus críticas a la dirección de la Comunión Nacionalista Vasca (la denominación del PNV desde 1916) precipitó en julio de 1921 una escisión de la que surgió dos meses después una nueva formación política: el PNV-Aberri, partido independentista creado sobre el modelo del Sinn Féin irlandés. En Cataluña, Francesc Macià constituyó el 18 de julio de 1922 el grupo Estat Català, sobre la base de las penyas nacionalistas y el sector separatista de la Joventut Nacionalista, que tras el fracaso de la campaña autonomista de posguerra se había separado de la Lliga en la Conferencia Nacional Catalana del mes anterior ${ }^{14}$.

13 Sobre la evolución de las Juventudes Socialistas en la inmediata posguerra, véase ARRANZ Notario, Luis: «Los cien niños y la formación del PCE», en Para una historia del PCE. Conferencias en la FIM, Madrid, 1980, pp. 85-104; «La ruptura del PSOE en la crisis de la Restauración: el peso del octubre ruso», Estudios de Historia Social (Madrid), no 32-33 (junio de 1985), pp. 7-91; y «La ruptura del PSOE en la crisis de la Restauración: debate ideológico y político», en JuLIÁ, Santos (coord.): El socialismo en España. Desde la fundación del PSOE hasta 1975, Madrid, 1986, pp. 161-189. Los datos de afiliados en GonZÁlez QuiNTANA, Antonio: «La primera organización de jóvenes proletarios...», op. cit., p. 35; Renovación, 15/1/1930, p. 1; y CRUZ, Rafael: «La organización del PCE (1920-1934)», en Estudios de Historia Social (Madrid), nº 31 (octubre-diciembre 1984), pp. 223312, p. 297.

14 GrANJA, José Luis de la: «Los mendigoizales nacionalistas: de propagandistas sabinianos a gudaris en la Guerra Civil», en Los Ejércitos, Vitoria, 1994, pp. 295-314; «MendigoizaleMendigoxale», en Enciclopedia General Ilustrada del País Vasco, Cuerpo A: Diccionario Enciclopédico Vasco, vol. XXVII. San Sebastián, 1989, pp. 503-510; y UCELAY DA CAL, Enric: Estat Català: The strategies of separation and revolution of catalan radical nationalism (1919-1933), tesis doctoral, Columbia University. Ann Arbor (Mi.)-Londres, University Microfilms International, 1989, 2 vol.; y «Joventut i nacionalisme radical català, 1901-1987», en UCELAY DA CAL, Enric, (dir.): La Joventut a Catalunya..., op. cit., vol. 1, pp. 182-199. 


\section{LA Dictadura de PRimo de Rivera y la MOVILIZACión eSTUdiantil}

El crecimiento económico producido durante la Primera Guerra Mundial favoreció un notable incremento del colectivo universitario, cuando los hijos de profesionales liberales y de pequeños negociantes que habían logrado amasar un pequeño capital se incorporaron a un mundo universitario donde se estaba gestando una auténtica revolución de los usos y las costumbres de la juventud, tanto en su organización interna como en sus relaciones con el resto de la sociedad $^{15}$. Pero la dictadura no pudo controlar esta renovación de valores, ni evitar que se fuera extendiendo a buena parte de la población, especialmente a la clase media urbana y a la juventud proletaria por la misma naturaleza independiente del hecho universitario. Obviamente, estos cambios hacen referencia sobre todo a los hombres jóvenes, dado que, como indica Mary Nash, las restricciones legales a la educación femenina superior se mantuvieron hasta 1910. A finales de los años veinte la situación había mejorado algo, pero la población universitaria femenina era todavía escasa y en todo caso, pocas mujeres ejercían sus profesiones después de obtener la licenciatura. Sin embargo, los cambios económicos y sociales también afectaron a la mujer: Jiménez de Asúa destacaba en 1929 que «donde la juventud muestra su mayor empuje y su más inédita faz, es en su sector femenino», pero también expresaba su preocupación por la posibilidad de que fueran atraídas por la Iglesia, temor que sería común en las filas de la izquierda durante la Segunda República cuando se concediese el derecho de voto a la mujer. También la Iglesia percibió claramente el potencial de esta movilización femenina, como muestra una carta pastoral del cardenal Segura publicada el 19 de mayo de 1929 que abogaba por la creación con carácter inmediato de una Juventud Católica Femenina ${ }^{16}$.

Se produjo, así, un mayor compromiso político de los jóvenes, desde posturas marcadamente radicales vinculadas con un mito republicano renovado, especialmente entre los jóvenes universitarios. La protesta estudiantil de la época puede interpretarse como un conflicto generacional que enfrentó a la tradicional élite del poder con los recién llegados a la vida política. El general Mola, responsable del orden público en los años finales de la Monarquía, señalaba la existencia de este conflicto incluso en el seno de los sectores más acomodados ${ }^{17}$.

15 Según Ben-Ami, Shlomo: Los orígenes de la Segunda República Española: Anatomía de una transición, Madrid, 1990, p. 98, la población universitaria llegó a duplicarse bajo la Dictadura: de 27.000 estudiantes en 1923 a casi 60.000 en 1929-30, mientras que apenas había aumentado un $8 \%$ en los ocho años precedentes.

16 NASH, Mary: Rojas. Las mujeres republicanas en la Guerra Civil, Madrid, 1999, p. 53; Juventud. Conferencia de Luis Jiménez de Asúa y réplica de José López Rey, Madrid, 1929, pp. 11-116, pp. 81 y ss., la cita en p. 81; la pastoral del cardenal Segura en pp. 95-96.

17 MaIner, José Carlos: «Cultura, 1923-1939», en TuÑón De LARA, Manuel (dir.): Historia de España, vol. IX. La crisis del Estado: Dictadura, República, Guerra (1923-1939), Barcelona, 1981, p. 570. MOLA VIDAL, Emilio, «Tempestad, calma, intriga y crisis. Memorias de mi paso por la Direc- 
La hostilidad juvenil se dirigía no sólo contra la vetusta clase dirigente de la Restauración, sino también contra los intelectuales y políticos de mediana edad —identificables con la «generación de 1914»- que habían fracasado en sus afanes de reforma del sistema. Como dice Santos Juliá, en el ámbito intelectual irrumpió entre 1925 y 1930 un grupo muy joven, que habían nacido más o menos con el siglo, hombres como Francisco Ayala, Rafael Alberti, Ramiro Ledesma o José Antonio Maravall, que se reunían y realizaban tertulias en los cafés de la capital y que, con la caída del dictador, se convencieron de que «las plumas debían ponerse al servicio de las ideas», aunque cuando esto se produjo, sus caminos se diversificaron. Pero la protesta universitaria permitió establecer un nexo de unión emocional entre los jóvenes y los patriarcas de la resistencia antidictatorial como Unamuno, Sánchez Guerra o Macià, radicalizando, potenciando y generalizando la protesta intelectual, acelerando el movimiento antimonárquico y haciéndolo asequible a amplias capas de las clases medias españolas ${ }^{18}$.

En un principio, el conflicto que polarizó la vida universitaria fue la cuestión de la representatividad estudiantil. A comienzos de los años veinte, las asociaciones laicas luchaban en condiciones de desigualdad con organizaciones confesionales como la Asociación de Estudiantes Católicos (AEC) y la Asociación Católica Nacional de Propagandistas (ACN de P), acusadas de ejercer una especie de «somatenismo estudiantil» contra la libertad de cátedra. Un decreto de 16 de septiembre de 1921 había favorecido la constitución de «asociaciones profesionales» de estudiantes a través de las cuales éstos pudieran intervenir en el gobierno de sus universidades, pero los grupos católicos trataron de disputar la representatividad estudiantil a los sindicatos profesionales. La tensión estalló en enfrentamientos violentos que llevaron a la clausura de la Universidad de Madrid, mientras que en otros centros educativos se declararon huelgas para protestar contra la injerencia de las organizaciones católicas.

A fines de 1924, un grupo de estudiantes republicanos fundó la Unión Liberal de Estudiantes (ULE) para contrarrestar la influencia de católicos y conservadores en la Universidad de Madrid. El 27 de marzo de 1925 se produjeron los primeros incidentes graves, en el transcurso del homenaje tributado por la Universidad Central a Angel Ganivet. La ocasión para realizar una verdadera labor reivindicativa de la libertad de educación y de ruptura con el sistema dictatorial la ofreció una cuestión no estrictamente política: el artículo número 53 de la Ley de Reforma Universitaria impulsada por el ministro de Instrucción Pública, Eduardo Callejo, que sancionaba la protección de la enseñanza privada, en especial la religiosa, equiparándola con la pública y permitiendo a los colegios de jesuitas y agustinos expedir títulos académicos. La protesta contra la «Ley Callejo» se inició como una respuesta corporativa a la plétora de licen-

\footnotetext{
ción General de Seguridad», en Obras Completas, Valladolid, 1940, p. 584.

18 Juliá, Santos: «Ser intelectual y ser joven, en Madrid, hacia 1930», en Historia Contemporánea (Bilbao), $\mathrm{n}^{\circ} .27$ (2003), pp. 749-77, pp. 752, 772 y 775; TUSELL, Javier y GARCÍA QUEIPO DE LLANO, Genoveva: Los intelectuales y la República, Madrid, 1990, p. 59.
} 
ciados en el seno de las profesiones liberales, y se materializó en una serie de huelgas estudiantiles en distintas universidades a partir del 15 de mayo, momento en que se produjo el primer gran enfrentamiento del dictador con los estudiantes, al sancionar con la expulsión y el confinamiento a uno de su dirigentes, Antonio $\mathrm{M}^{\mathrm{a}}$ Sbert ${ }^{19}$.

En enero de 1927, Sbert y Antolín Casares crearon la Federación Universitaria Escolar (FUE) de Madrid, que a pesar de su carácter teóricamente profesional, aconfesional y apolítico mantenía una línea de pensamiento liberal y socialista, opuesta tanto al primorriverismo como a las asociaciones católicas que habían asumido de forma oficiosa la representación de los estudiantes a partir del golpe de septiembre de 1923. En mayo de 1928, la FUE protagonizó su primera huelga, en protesta por la suspensión dictada contra el catedrático Luis Jiménez de Asúa ${ }^{20}$, y a fines de año convocó manifestaciones contra los privilegios académicos concedidos a los centros religiosos de Deusto y El Escorial. Por ese entonces, la organización estudiantil basaba su programa en la reivindicación de nuevos valores socioculturales, como el feminismo y el naturismo, pero no mostraba una ideología clara, salvo un vago republicanismo sentimental que, poco a poco, conseguiría plasmarse políticamente. El 27 de febrero de 1929 comenzó una nueva oleada de protestas, y el 7 de marzo se inició una nueva huelga, que culminó tres días después con la ocupación militar de las facultades madrileñas. Los conflictos tuvieron un enorme eco público, al constituir las primeras manifestaciones callejeras contra la dictadura y la monarquía. Ante la intransigencia del gobierno, a partir del día 13 la huelga se extendió por diferentes provincias, y el día 16 el Directorio promulgó un decreto por el que se clausuraba la Universidad Central hasta el 1 de octubre de 1930. La protesta estudiantil se fue cohesionando, y tras lanzarse un manifiesto al país el 1 de abril, en que destacaban que pertenecían «a la clase media» y que iban a la huelga "por imperativo del más puro patriotismo, en patriótica defensa de los intereses nacionales que más directamente nos afectan», se organizó una Junta Central del Movimiento Escolar ${ }^{21}$. El 5 de abril se reabrieron los

19 LÓpeZ-REY, José: Los estudiantes frente a la Dictadura, Madrid, 1930, pp. 7-8.

20 Luis Jiménez de Asúa destacaría posteriormente el papel de los jóvenes, en una conferencia en la Casa del Pueblo de Madrid el 14 de mayo de 1929 (Juventud, op. cit., p. 17).

21 Sobre el conflicto estudiantil, véanse BEN-AMI, Shlomo: Los orígenes de la Segunda República..., op. cit., pp. 101-117; CAUDET, Francisco: «Estudiantes y profesores frente a la dictadura. Antecedentes de la generación del 36», en Tiempo de Historia (Cádiz), no 8 (julio de 1975), pp. 4-15; GARCÍA QUEIPO DE LlANO, Genoveva: «La rebelión de los estudiantes y la movilización intelectual contra la Dictadura (1929)», en Boletín de la Real Academia de la Historia (Madrid), tomo CLXXXIV, cuaderno II (mayo-agosto 1987), pp. 319-357; JATO MIRANDA, David: La rebelión de los estudiantes, Madrid, 1975 (4ª ed.), pp. 84-93; LÓPEZ DE OCHOA, Eduardo: De la Dictadura a la República, Madrid, 1930, pp. 170-186; PÉREZ, Dionisio: La Dictadura a través de sus notas oficiosas, Madrid, 1930, pp. 239-249; y Villanueva, Francisco: El momento constitucional, 2a ed., Madrid, 1929, pp. 100-121. El manifiesto se reproduce en LÓPEZ REY, José: Los estudiantes..., op. cit., pp. 100-103, las citas en pp. 100-101. 
centros educativos de provincias, pero tres días después se recrudecieron los disturbios. Las clases se reanudaron los días 24 y 25, aunque en Madrid el plazo de normalización de la actividad académica se prorrogó hasta el 27 . La FUE no aceptó de buen grado esta concesión, pero la mayor parte de los estudiantes acordó reincorporarse a las aulas. Ello no quería decir que los universitarios renunciaran a atacar a la "Ley Callejo», sino que se mostraban dispuestos a continuar la guerra trabada con el Ministerio hasta transformar un problema de segunda fila en una cuestión de política nacional. Y es que los estudiantes analizarían la dictadura en términos generacionales: «es antijuvenil (...). No trae, ni se lo propone, un nuevo sentido de las cosas. No vino a rejuvenecer, sino a desempolvar» ${ }^{22}$.

Tras haber logrado una efímera normalización académica, la Dictadura intentó canalizar en lo posible la agitación estudiantil potenciando in extremis su casi inexistente brazo juvenil, organizado formalmente en $1924^{23}$. La primera Asamblea Nacional de las Juventudes de Unión Patriótica se celebró en Zaragoza del 15 al 17 de mayo de 1929, pero ni La Nación, órgano oficial del primorriverismo, ni el Comité Ejecutivo Nacional de la UP otorgaron excesiva importancia a esta reunión ${ }^{24}$, lo que daba muestra de la escasa proyección de futuro del intento, o el temor de la elite dirigente a potenciar en el seno del partido una tendencia renovadora que, caso de radicalizarse, podía dar lugar a alternativas algo distantes de la pura y simple dictadura paternalista.

Ante la proximidad de una reunión del Consejo de la Sociedad de Naciones en Madrid, Primo de Rivera multiplicó los signos de buena voluntad: el día 19 de mayo restableció la vida académica, anulando las sanciones e intervencionismos, y en la Gaceta del 24 de septiembre apareció la derogación del polémico artículo 53 de la «Ley Callejo». Pero el enfrentamiento de los estudiantes con Primo ya había desbordado el ámbito meramente académico. La FUE deseaba ir más lejos, y exigió la rehabilitación de Sbert, la reintegración de cinco profesores expulsados y el reconocimiento de las asociaciones estudiantiles in-

22 «Réplica en nombre de la mocedad de José López Rey», en Juventud, op. cit., pp. 117-162, p. 150 .

23 Sobre la organización de secciones juveniles de la UP, véanse Archivo Histórico Nacional (AHN), Presidencia, Directorio Militar, leg. 192, caja 1, exp. 12.941 y los artículos de La Vanguardia, 2/1/1929, 3/1/1929, 15/1/1929, 14/2/1929 y 19/3/1929. El único estudio existente sobre las juventudes «upetistas» es el de Quiroga FERnÁndeZ DE SOTO, Alejandro: «Perros de paja: las Juventudes de la Unión Patriótica», en Ayer (Madrid), n 59, 2005 (3), pp. 69-96.

24 Véase programa de la Asamblea y reportaje sobre la misma en Unión Patriótica, 15/4/1929, pp. 1-3 y 1/6/1929, pp. 15-20. Reseñas de la reunión: «La Asamblea Nacional de Juventudes de Unión Patriótica de Zaragoza», La Nación, 16/5/1929, p. 7 y 17/5/1929, p. 7. El dinamismo y la modernidad de los usos políticos de la Juventud de UP en relación con la atonía conservadora reinante en el resto del partido son destacados por Álvarez ReY, Leandro: Sevilla durante la Dictadura de Primo de Rivera: La Unión Patriótica (1923-1930), Sevilla, 1987, pp. 118-127. Sobre la Asamblea Nacional de las juventudes «upetistas» en Zaragoza, véase FERNÁndeZ CLEMENTE, Eloy: Gente de orden. Aragón durante la Dictadura de Primo de Rivera, Zaragoza, 1995-1998, vol. I, pp. 254-256. 
dependientes. La agitación estudiantil volvió a ganar las universidades en el segundo trimestre del curso 1929-1930. Acosado desde todos los frentes, Primo respondió a inicios de 1930 disolviendo la FUE, que decidió entonces ir a la huelga. El 22 de enero estalló un paro general universitario de carácter nacional y con un neto carácter republicano, que fue apoyado por las fuerzas sindicales. Primo abandonó el poder seis días después. En este proceso, las juventudes socialistas jugaron un papel secundario. En su Cuarto Congreso, celebrado en febrero de 1932, reconocían que "no hemos tenido relación alguna» con los movimientos estudiantiles habidos durante la dictadura de Primo de Rivera y que su influencia «en los medios escolares ha sido relativamente escasa» 25 .

Con la llegada al gobierno del general Berenguer, el movimiento universitario fue politizando sus acciones en sentido cada vez más inequívocamente antidinástico, hasta transformarse en uno de los protagonistas clave del enfrentamiento con el régimen. En febrero y marzo de 1930, muchos miembros de la FUE comenzaron a inscribirse en la Asociación de Estudiantes Republicanos afín a la Alianza Republicana, y del 21 al 27 de abril se celebró el congreso de la Unión Federal de Estudiantes Hispanos (UFEH), para unir a escala estatal las FUE locales, que con 70 asociaciones y 15.882 asociados alcanzaron en la primavera de 1930 su cenit de popularidad y de influencia. El irresistible impulso republicano fue arrinconando poco a poco a la AEC. Fue entonces cuando los estudiantes alfonsinos más decididos comenzaron a crear por su cuenta grupos de acción callejera ya decididamente contrarrevolucionarios, como la Juventud Monárquica fundada en Madrid en abril de 1930, que mantenía ciertas vinculaciones con la aún existente Juventud Maurista, y que alcanzó una discreta difusión en algunos núcleos locales juveniles de otras zonas de España merced a la organización de actos de «afirmación monárquica» ${ }^{26}$. Un mes antes que el grupo anterior había nacido la Juventud Monárquica Independiente, agrupación fantasmal de hijos de buena familia presidida por Eugenio Vegas Latapié, que no parecía vinculada a ningún partido en concreto. Este grupúsculo, que parece que era instrumentalizado por personas del entorno de la ACN de $\mathrm{P}$, preconizaba una reacción agresiva y autoritaria, aunque no de contornos fascistas, que salvase a la Monarquía. Vegas Latapié intentó en vano transformar a la Juventud Monárquica Independiente en un grupo similar a los maurrasianos Camelots du Roi, con el propósito de lanzarlos desde fines de 1930 a la lucha contra la FUE en su propio terreno, con el apoyo de otros grupúscu-

25 Federación de Juventudes Socialistas de EsPaÑa: IV Congreso Nacional (convocatoria y orden del día), Madrid, 1932, pp. 14 y 15.

26 ABC, 15/4/1930, pp. 27 y 24. Según Gil Pecharromán, Julio: Conservadores subversivos. La derecha autoritaria alfonsina (1913-1936), Madrid, 1994, p. 75, la Juventud Monárquica se inspiraba parcialmente en algunas organizaciones juveniles de extrema derecha como los Camelots du Roi, los integralistas portugueses o las guardias cívicas de posguerra. Véase también BEN-AMI, Shlomo: Los orígenes de la Segunda República..., op. cit., p. 251. 
los de la extrema derecha y en connivencia con la policía de Mola ${ }^{27}$. El resultado fue decepcionante: ni las algaradas contra el movimiento estudiantil de izquierda ni la publicación de manifiestos lograron desviar la corriente antimonárquica que arrastraba al conjunto de la juventud estudiantil ${ }^{28}$. La juventud monárquica era demasiado débil y tradicional como para resultar atractiva a los jóvenes pequeñoburgueses de extrema derecha, algunos de los cuales se mostraban más proclives a militar en movimientos con un mensaje aparentemente más «moderno», como el populismo interclasista y autoritario de la Unión Monárquica Nacional heredera del «upetismo» o el pseudofascismo tradicionalista del naciente Partido Nacionalista Español liderado por el doctor José María Albiñana.

El 22 de enero de 1931, la solicitud estudiantil de derogación del Código Penal de la dictadura, de libertad para los estudiantes y profesores no sujetos a procedimiento judicial y de castigo para los agentes y «legionarios de Albiñana» que habían maltratado a algunos estudiantes condujo a una nueva huelga general que se extendió a todo el país. Dada la cada vez mayor sintonía de los estudiantes con los grupos revolucionarios republicanos, Berenguer otorgó el 5 de febrero un mes de vacaciones forzadas. Del 2 al 5 de marzo, el Gobierno permitió la apertura de las distintas universidades, pero fueron los «Sucesos de San Carlos» de los días 24 y 25 los que revistieron mayor gravedad y tuvieron consecuencias más amplias. Suspendidas las clases, el director General de Seguridad Emilio Mola ordenó el día 24 un espectacular despliegue de las fuerzas de orden público frente a la facultad de Medicina, en la calle Atocha de Madrid. La hora y media de enfrentamientos finalizó a mediodía con unas descargas que causaron dos muertos y 16 heridos, once de los cuales eran estudiantes. Al día siguiente, los enfrentamientos violentos continuaron en las calles de Madrid, mientras que los estudiantes de Valencia, Alicante, Zaragoza, Huesca, Albacete, Logroño, Valladolid, Sevilla y Salamanca se amotinaban en señal de solidaridad, levantaban barricadas y disparaban contra las fuerzas de orden público. En Barcelona se declaró la República en la Universidad, y la FUE, jaleada por la prensa de izquierda, exigió la dimisión inmediata del director de Seguridad ${ }^{29}$.

Suprimidas de nuevo las garantías constitucionales el 26 de marzo, el movimiento estudiantil se convirtió en el abanderado de la opción antimonárqui-

27 Ben-Ami, Shlomo: «The Forerunners of Spanish Fascism: Unión Patriótica and Unión Monárquica», en European Studies Review (Londres), vol. 9, nº. 1(enero 1979), p. 62.

28 Los frecuentes choques de la FUE con estos grupos monárquicos, en ALCALÁ Galiano, Álvaro: La caída de un trono (1931), Madrid, 1933, pp. 60 y 97.

29 Narración de los sucesos de San Carlos desde diferentes perspectivas, en MOLA VIDAL, Emilio: «El derrumbamiento de la Monarquía», en Obras Completas, op. cit., pp. 763-815 y 881-923; y VIDARTE, Juan Simeón: No queríamos al rey. Testimonio de un socialista español, Barcelona, 1977, pp. 367-370. Los procesos ulteriores para depurar las responsabilidades de Mola en los hechos, en AHN, Tribunal Supremo, Fondo Reservado, Sumario 295, exp. no 29 y AHN, Tribunal Supremo, Fondo Reservado, Causa 1776/1931, exp. no 4. 
ca. Pero el ala más extremista de la FUE, representada por el periódico Rebelión, amenazaba con superar los objetivos políticos del movimiento republicano, y con arrastrar a los obreros hacia una huelga general insurreccional. La CNT no dudó en aplaudir la «madurez revolucionaria» de la FUE como organización de vanguardia que podía rebasar las expectativas de los partidos republicanos, los cuales habían vuelto a la clandestinidad tras la intentona revolucionaria frustrada de diciembre. Ante el peligro de una nueva edición de la intentona de Jaca o de un golpe militar involucionista, republicanos y socialistas decidieron frenar al movimiento estudiantil, y esperar al veredicto electoral de abril. Los conflictos estudiantiles cesaron, pero para ese entonces el régimen monárquico vivía sus últimos días de vida ${ }^{30}$.

\section{LA SEGUNDA REPÚBLICA Y EL AUGE DE LOS MOVIMIENTOS JUVENILES}

El protagonismo de la juventud fue uno de los fenómenos más destacados de la política española en los años treinta. La implantación de un régimen democrático en abril de 1931, impulsó el desarrollo de nuevas organizaciones de masas y llevó a los partidos a adaptar sus estructuras organizativas intensificando el activismo de sus afiliados y simpatizantes, especialmente de los jóvenes. Una característica destacada de la vida política fue el desarrollo de organizaciones específicamente juveniles vinculadas a los distintos partidos, que vivieron un periodo de gran desarrollo. Un ejemplo del crecimiento de estas organizaciones es el de la FJS, que pasó de reconocer unos 1.500 afiliados en su congreso de 1929 a 12.000 en su cuarto congreso, en febrero de 1932, y a más de 20.000 en el quinto, en abril de $1934^{31}$.

Las organizaciones juveniles tuvieron un papel importante, si no principal, en la conflictividad social y política del periodo, y fueron la vanguardia de nuevos tipos de acción colectiva y nuevas formas organizativas para desarrollarlas. Prácticamente todas las organizaciones juveniles mantuvieron planteamientos más radicales que los de sus respectivos partidos e intentaron ampliar su autonomía con respecto a éstos: la radicalización fue la característica más destacada de su acción política y confundieron frecuentemente sus propias aspiraciones con las de la juventud que decían representar. Las razones de esta opción generacional por el extremismo son complejas, y tienen que ver con la revalorización del universo contestatario general en la Europa de posguerra, pero también con el éxito político de la movilización estudiantil en contra de la dictadura y con las trabas puestas al natural deseo de emancipación económica de los jóvenes por la incer-

30 BeN-Ami, Shlomo: The Forerunners of Spanish Fascism», op. cit., pp. 388-389.

31 Federación de Juventudes Socialistas: Memoria del IV Congreso, Madrid, 1932, p. 6 y Memoria del V Congreso, Madrid, 1934, p. 13. También se produjo un crecimiento de la UJCE, que contaba con algo más de 11.000 militantes en julio de 1933 (CruZ, Rafael: «La organización del PCE ...", op. cit., p. 297). 
tidumbre de la crisis económica que se cernió sobre España a partir de 193132 , reduciendo las posibilidades de promoción estudiantil y profesional de los jóvenes de clase media y baja.

Los partidos mantuvieron una relación equívoca y conflictiva con sus organizaciones juveniles, ya que buscaron alentar su activismo sin verse obligados a otorgarles una participación real en la toma de decisiones políticas. El fomento de secciones juveniles fue realizado de forma muy variada por los diferentes grupos políticos, y no siempre se vio coronado por el éxito. La acción política juvenil y la dinámica partidista fueron fenómenos relacionados: los jóvenes hallaron en los partidos políticos un marco de actuación donde poder expresar sus actitudes inconformistas con mayor eficacia. Por su parte, los dirigentes de las formaciones partidistas canalizaron la vocación política de la juventud con el objetivo de obtener mayores cotas de militancia, pero temían que su radicalización les pusiera fuera de su control.

Los partidos republicanos, que conservaban la impronta de los partidos de notables, fracasaron en la creación de un potente movimiento juvenil. El cada vez más conservador Partido Republicano Radical patrocinó en 1932 la celebración de un I Congreso Nacional de las Juventudes Radicales y Autónomas de España, donde se planteó la necesidad de crear una Federación de Juventudes Republicanas. Un reto que fue abordado con mayor éxito por los republicanos de izquierda: al año siguiente, la Juventud de Acción Republicana pretendió constituir una Federación Juvenil Republicana formada por las Juventudes Federales, las radical-socialistas independientes y las de su propio partido. La Juventud de Acción Republicana y la Juventud Radical Socialista Independiente también vivían su propio proceso de radicalización: el 4 de noviembre de 1933 se quejaron de «la labor antirrepublicana y antipatriótica» del gobierno de Lerroux, y expresaron su voluntad de lanzarse a la calle «unidos a los proletarios», porque «antes que Alemania, preferimos para nuestro país un régimen análogo al de Rusia». A partir de 1934, las Juventudes de Izquierda Republicana cubrieron en parte estas pretensiones de «unidad republicana» al unificar a la organización juvenil de Acción Republicana con la de los radicalsocialistas escindidos del viejo partido radical ${ }^{32}$.

Las formaciones políticas de la derecha española partieron de cero en la formación de sus contingentes juveniles. La excepción la constituye el caso, por tantas razones especial, de las juventudes tradicionalistas. La proclamación de una República con un profundo programa laicizador estimuló el desarrollo de la juventud carlista: la Juventud Española Tradicionalista y su filial estudiantil la Asociación Escolar Tradicionalista (AET), creada en la primavera de 1930, mantuvieron e incluso intensificaron sus actividades políticas, pero agudizaron sus críticas a una jefatura partidista cada vez más acomodaticia. Aunque a inicio de 1934 la

32 AHN, Audiencia Territorial de Madrid, Criminal (ATM [Cr.]), leg. 205/1, juzgado nº. 18, causa 349/33; Avilés FARRÉ, Juan: La izquierda burguesa en la Segunda República, Madrid, 1985. 
dirección carlista proclamaba contar con 803 secciones juveniles en toda España, su control sobre este potencial vivero de activistas era puramente nominal. La llegada al secretariado general del partido de una figura carismática y renovadora como Manuel Fal Conde cambió la situación: el 22 de mayo, las actividades de la juventud, hasta entonces regidas por la más anárquica descentralización, fueron coordinadas por una Delegación Especial de Juventudes, en cuyo ámbito de actuación se incluía a la AET. Desde ese momento el protagonismo militante de las juventudes, en sintonía con los objetivos de Fal Conde, resultó incuestionable, como también lo fue su directa implicación en las actividades violentas que condujeron a la conspiración antirrepublicana y a la guerra civil ${ }^{33}$. Los grupos herederos de la monarquía alfonsina y de la dictadura de Primo de Rivera, no pasaron en los primeros compases de la República de la simple banda callejera. Las Juventudes del viejo partido oficialista Unión Patriótica (virtualmente disueltas tras la muerte del dictador), la Juventud Monárquica, la Juventud Monárquica Independiente y la Juventud Nacionalista Española del protofascista Partido Nacionalista Español (PNE) tuvieron sólo un mero papel testimonial.

El caso más interesante, tanto por su importancia numérica como por sus complejas relaciones con el liderazgo del partido, lo ofrece la Juventud de Acción Popular (JAP), afín a la Confederación Española de Derechas Autónomas (CEDA) la gran organización de masas de la derecha conservadora católica en el período republicano. Como partido católico accidentalista de nueva creación, Acción Nacional (el precedente inmediato de la CEDA) recurrió a los elementos de socialización y de organización disponibles en ese momento en el movimiento confesional juvenil: organizaciones como la Juventud de Acción Católica de Espa$\tilde{n} a^{34}$, que se transformó en una auténtica cantera de dirigentes de la JAP; congregaciones religiosas como la Agrupación San Luis Gonzaga ${ }^{35}$, o asociaciones estudiantiles como la Confederación Nacional de Estudiantes Católicos de España (CECE), fundada en 1921 y dividida en federaciones provinciales, muchas de las cuales se distinguieron por sus violentas diatribas contra la política religiosa del gobierno republicano-socialista en el poder hasta el otoño de 1933.

En octubre de 1931 se proyectó la creación de la Juventud de Acción Nacional (JAN) sobre el modelo de la Unión Católica Belga, como organización

33 Véanse al respecto las memorias del dirigente juvenil carlista navarro BuRGO, Jaime del: Conspiración y Guerra Civil, Madrid-Barcelona, 1970.

34 En su congreso de 1932, la JAC afirmaba tener 12.000 afiliados. La Juventud Católica Femenina decía, en junio de 1934, contar con 6.000 afiliadas (MONTERO GIBERT, José Ramón: La CEDA. El catolicismo social y político en la II República, Madrid, 1977, vol. 2, pp. 518 y 521).

35 La Agrupación San Luis Gonzaga, conocida popularmente como los «Luises», fue una de las primeras asociaciones estudiantiles españolas. Creada en el último tercio del siglo XIX, en la crisis final de la Monarquía sus integrantes se aplicaron en ejercicios de formación premilitar y engrosaron las filas de algunos grupúsculos monárquicos. En ciudades como Valladolid, se ganaron durante la República una justificada fama de violencia, y apoyaron los primeros pasos del fascismo local, liderado por Onésimo Redondo. 
defensora del orden en los actos públicos del partido, y escuela de formación política de los futuros dirigentes. La JAN nació oficialmente el 22 de febrero de 1932, como sección autónoma de Acción Nacional, — tanto la organización juvenil como el partido adoptarían el adjetivo "popular», al prohibir el gobierno republicano el apelativo nacional en los grupos políticos- aunque todo miembro de la juventud se transformaba automáticamente en militante del partido, buscando engrosar de este modo su organización con núcleos juveniles a los que el partido llegaba con dificultad. Las veleidades fascistizantes y antisocialistas del movimiento se hicieron más intensas, mientras que la actitud de los líderes cedistas, y concretamente de José María Gil Robles, ante la actuación de la JAP fue más que ambigua. Su militancia era de una extracción interclasista similar a la del partido: profesionales liberales, obreros, comerciantes y empleados. Al estilo de Acción Católica, los grupos de distrito estimularon la creación de círculos de estudio sobre temas sociales, filosóficos y políticos, pero sus actividades principales se enfocaron a la propaganda, la acción cultural y el deporte entendido como un modo de militancia que no excluía la acción callejera. En 1933 se produjo la consolidación de la JAP como el gran movimiento juvenil de la derecha española, que vio cómo su presidente, José María Valiente, era nombrado secretario general del partido. Tras la defección de los monárquicos alfonsinos a inicios de año y el ascenso al poder del partido nazi, se produjo entre la juventud accidentalista un creciente proceso de radicalización ${ }^{36}$.

En marzo de 1933, al constituirse la CEDA, la JAP presentó una enmienda en la que se proponía que la nueva confederación se declarase opuesta al sufragio universal y al parlamentarismo, que no fue aceptada. La dirección cedista siempre intentó evitar una excesiva autonomía de sus juventudes, cuyo Comité Nacional fue colocado bajo la dependencia directa del Consejo Nacional de la CEDA. Los límites de edad impuestos para la militancia (de 16 a 35 años), pretendían evitar tensiones entre la jerarquía del partido y una sección juvenil maximalista, y permitía a los miembros más «mayores» hacerse con la dirección de la entidad juvenil. Tras la victoria electoral de noviembre de 1933, la JAP incrementó su radicalismo verbal antidemocrático y antisocialista. En febrero de 1934 impulsó la creación de una sección de «movilización civil» para «prestar los servicios públicos necesarios a la población» en caso de una huelga general. Sus miembros desempeñaron un importante papel contrarrestando los efectos de los paros convocados a lo largo de dicho año. La presencia de la CEDA en el Gobierno después de octubre de 1934, y el inicio de la aplicación por parte de su líder máximo, José María Gil Robles, de una táctica de conquista gradual del poder político agudizaron la radicalización de la JAP en un sentido filofascista. A la altura de las elecciones de febrero de 1936, la JAP era la formación juvenil derechista más numerosa, con un millar de comités y 225.000

36 Sobre la organización, estructura, dirigentes y afiliados de la JAP véase MONTERO GIBERT, José Ramón: $L a C E D A \ldots$, op. cit., vol. I, pp. 582-656. MONGE y BERNAL, José: Acción Popular (Estudios de biología política), Madrid, p. 266. 
afiliados, de ellos 3.500 en Madrid ${ }^{37}$, pero el fracaso electoral de 1936 desmoronó la organización.

El fascismo español aparece desde su mismo origen como una opción netamente juvenil, opuesta tanto a la elite política gobernante como a los movimientos juveniles influidos por ideologías y poderes foráneos. La propia Falange Española surgió de la convergencia de tres grupos eminentemente juveniles: las Juntas Castellanas de Actuación Hispánica creadas en agosto de 1931 sobre la base de las juventudes clericales vallisoletanas vinculadas a la Compañía de Jesús, que se fusionaron en octubre de ese año con el grupo de intelectuales radicales reunidos desde marzo en torno a la revista La Conquista del Estado (que se autorrepresentaban como «falanges jóvenes» de entre 18 y 45 años) 38 ; y la Falange Española, fundada por José Antonio Primo de Rivera en octubre de 1933 con el patrocinio indirecto de algunas agrupaciones juveniles residuales procedentes del maurismo y de la Unión Patriótica. La convergencia, el 14 de febrero de 1934, de estas tres tendencias en Falange Española y de las JONS pretendía ser la expresión de toda la juventud, por lo que se anunció que regiría en la organización el principio de recusar para los mandos a los mayores de 45 años. La crítica generacional era tan intensa como su hostilidad a los grupos juveniles ideológicamente rivales, no sólo los de obediencia marxista o separatista, sino a la teóricamente más próxima JAP.

Dado el gran poder de atracción del movimiento cedista sobre las juventudes conservadoras, Falange no logró atraer sino a un grupo bastante reducido de intelectuales de clase media y media-alta cuya edad oscilaba entre los 25 y los 30 años. Su principal cantera fue, desde noviembre de 1933, el Sindicato Español Universitario (SEU), al que se agregaron los estudiantes de Bachillerato. El SEU, que reunió a unos 400 estudiantes y a otro centenar de «militantes» organizados en escuadras para pelear en las calles, fue el auténtico motor activista de Falange, cuya Junta de Mando tuvo buen cuidado de separar su estructura orgánica de la del partido para evitar interferencias de la justicia ${ }^{39}$. Sin embargo, como empresa de dinamización política de la juventud en sentido totalitario, Falange Española fue un rotundo fracaso. Si a fines de 1933 sus afiliados no pasaban de 2.000, un año después apenas alcanzaba la cifra de 5.000, y a inicios de 1936 contaba con unos 8.000 militantes, aunque esta cifra se podía triplicar con los estudiantes menores de 21 años a los que legal-

37 SAEZ MARÍN, Juan: «Asociacionismo juvenil en España...», op. cit., p. 64; MONTERo GIBERT, José Ramón: $L a C E D A .$. , op. cit., vol. 2, véase pp. 638-640, estatutos de la JAP; José M ${ }^{\mathrm{a}}$ VAliente, Ponencia $24^{\mathrm{a}}$ del Congreso de la J.A.P. en Madrid, cit. por MONGE Y Bernal, José: Acción Popular..., op. cit., p. 307; GonZÁlez CAlleja Eduardo y ReY RegullLo, Fernando del: La defensa armada contra la revolución. Una historia de las "guardias cívicas» en la España del siglo XX, Madrid, 1995, p. 237. JAP, 8/2/1936, p. 1.

38 La Conquista del Estado, 28/3/1931, p. 1. Este grupo logró integrar a unos 400 estudiantes a inicios de 1933.

39 PAYNE, Stanley G.: Falange. Historia del fascismo español, París, 1965, p. 45. 
mente ya se había prohibido afiliarse ${ }^{40}$. El fracaso electoral de la CEDA propició una defección en masa de los elementos más radicalizados de la JAP (se calcula que entre 10 y 15.000) hacia la teóricamente más combativa, Falange que, prácticamente en la clandestinidad desde mediados de marzo, se vio imposibilitada de encuadrarlos.

Los nacionalismos periféricos vasco y catalán gestionaron la participación política de la juventud de manera diferente. La combatividad catalanista aparecía identificada desde los años veinte con el extremismo de su facción juvenil ${ }^{41}$. Constituida la Esquerra Republicana de Cataluña (ERC) en marzo de 1931, la Joventut d'Esquerra Republicana-Estat Català (JEREC) comenzó a organizarse ese mismo verano, cuando se vislumbraba como inevitable la aceptación del marco jurídico-constitucional español. Ello llevó a los jóvenes independentistas, en su mayor parte estudiantes y empleados del sector servicios, a expresar su creciente frustración ante la «moderación» mostrada por los dirigentes de ERC en el poder, y a dirigir sus esfuerzos a una tarea de «nacionalización» de Cataluña que tuvo su plasmación práctica en el desarrollo de un populismo autoritario basado en un ejecutivo fuerte y un partido único, en un patriotismo exacerbado que imponía la subordinación del movimiento obrero anarquista (de ahí el acoso violento a que se sometió a la CNT), y en una hipervaloración de conceptos autoritarios como la disciplina, la obediencia y el liderazgo, que se reflejaron en su propensión por la acción violenta de corte paramilitar ${ }^{42}$. Esta apuesta por el nacionalismo autoritario y excluyente, que situó a alguno de su líderes en la órbita del fascismo, explica la actuación destacada que tuvo la JEREC en el levantamiento revolucionario del 6 de octubre de 1934. La consiguiente suspensión del gobierno autónomo, indujo a una moderación del discurso político de la Esquerra que no fue bien aceptado por la mayoría de sus juventudes. En mayo de 1936, buena parte de los afiliados a la JEREC abandonó el partido para formar el nuevo grupo independiente Joventut d'Estat Català, que al mes siguiente se vincularía al Partit Nacionalista Català y a otros grupos abiertamente separatistas. No se reunificarían hasta después del fracaso del golpe militar de julio en Barcelona.

De todos los partidos que actuaron en el País Vasco durante la Segunda República, el Partido Nacionalista Vasco era el que contaba con una base más joven ${ }^{43}$. A pesar de sus remotos orígenes y de su destacado papel en la radicalización en sentido separatista de un sector del nacionalismo vasco en 1921, las juventudes del PNV no practicaron de forma habitual esa estrategia de «tensión

40 PAYNe, Stanley G.: Falange..., op. cit., pp. 68-69. En p. 82 calcula unos 10.000 falangistas y unos 15.000 miembros del SEU en la primavera de 1936.

41 UCELAY DA CAL, Enric: «Violencia simbólica y temática militarista en el nacionalismo radical catalán», en Aróstegui, Julio (ed.): Violencia y política en España, en Ayer (Madrid), n ${ }^{\circ} 13$ (1994), p. 239.

42 Culla I Clara, Joan B.: «L'extrema dreta à Catalunya durant la Republica. Els 'ultres' d'abans de la guerra», en L'Avenç (Barcelona), nº 6 (octubre, 1977), pp. 160-161.

43 Granja SAINZ, José Luis de la: El nacionalismo vasco: un siglo de historia, Madrid, 1995, p. 157. 
generacional» característica de otras formaciones partidistas. Encuadradas desde edad muy temprana en entidades infantiles («umetxus» para niños y «poxpoliñas» y «neskatillas»), adolescentes (Euzko-Gastetxu-Batza o Federación de Chicos Vascos), juveniles (Euzko Gastedi o Juventudes Vascas), deportivas (EuzkoMendigoxale-Batza o Federación de Montañeros Vascos) o estudiantiles (EuzkoIkasle-Batza o Federación de Estudiantes Vascos) mantenían un alto grado de implicación y participación en las funciones sociales del PNV, aunque intervenían de forma poco activa en la toma de decisiones políticas. Por ello, algunos grupos juveniles como la Juventud de Bilbao se erigieron en portavoces oficiosos de la ortodoxia doctrinal del fundador de PNV, Sabino Arana, y del radicalismo independentista frente al autonomismo posibilista de la dirección del partido.

El desarrollo de las organizaciones juveniles de los diferentes partidos pudo ser uno de los factores que influyera en la decisión de crear una organización juvenil anarcosindicalista, la Federación Ibérica de Juventudes Libertarias (FIJL), a propuesta de un grupo de jóvenes de la organización de Madrid: la memoria de su congreso constitutivo, celebrado en julio de 1932, dice que el objetivo era crear «un organismo que recogiera los entusiasmos revolucionarios de la gran cantidad de jóvenes que entonces comenzaba a afluir a los Sindicatos» y que había influido «poderosamente» en esta decisión «el deseo de apartar de las organizaciones políticas a la juventud rebelde, pero inconsciente». Cuando se organizó, la FIJL decía contar con 85 secciones y aproximadamente 5.000 afiliados. Este número no incluía la militancia juvenil en Cataluña, el centro del anarcosindicalismo, donde se organizaron como juventudes autónomas con el nombre de Juventudes Libertarias (JJ.LL.), y no se integrarían en la FIJL hasta la guerra civil. Al igual que había pasado cuando se creó la FJS, algunos militantes libertarios consideraron que la organización juvenil no era necesaria ${ }^{44}$. Pero también algunos dirigentes anarquistas, como Manuel Buenacasa, identificaron al sector más radical (los faístas) de la CNT con la juventud, mientras que el sector más moderado y sindicalista (los treintistas) serían de mayor edad. Susanna Tavera ha demostrado que esta diferencia existía, al menos entre los dirigentes, mientras que Chris Ealham ha destacado la escasa edad de los «expropiadores» relacionados con la CNT que actuaban en la Barcelona republicana, y de los participantes en el ciclo insurrección anarquista, en su mayoría «obreros jóvenes, solteros y no cualificados», lo que relaciona no solo con el hecho de que a los jóvenes les resultaba más fácil aceptar el coste potencial de un enfrentamiento frontal con las fuerzas estatales por sus menores responsabilidades familiares, sino también con la falta de oportunidades de los jóvenes obreros ${ }^{45}$.

44 FIJL, Comité Peninsular: Memoria del congreso constitutivo de la Federación Ibérica de Juventudes Libertarias celebrado en Madrid durante los días 22, 23 y 24 de junio de 1932, Barcelona, 1938, International Institute of Social History (Amsterdam), Archivo de la CNT, microfilm 257, A.1; MORO, Fabián: Las juventudes Libertarias en España. Análisis espectral, Drancy, 1970, en UCELAY DA CAL, Enric (dir.): La joventut a Catalunya..., op. cit., vol. 2, pp. 177-180, p. 177.

45 TAvera, Susanna: «Escola de Rebel.lia...», op. cit., pp. 142-143; EALHAM, Chris: La lucha por..., op. cit., pp. 210, 225, 238 y 248, la cita en p. 225. 
Las relaciones entre el PSOE y la FJS fueron constante objeto de conflicto entre ambas organizaciones, acrecentados por la creciente división interna del movimiento socialista en los años republicanos y por la reivindicación de la juventud, no sólo de autonomía sino de su capacidad y derecho a intervenir con voz propia en este conflicto interno e intentar imponer sus propios puntos de vista: desde Renovación se rechazó que las Juventudes Socialistas fueran «órganos secundarios» del PSOE. Por el contrario, eran sus «fuerzas de choque», mientras el partido siguiera una línea en consonancia con la izquierda socialista, pero si se «desviara» de ésta «no nos consideraríamos obligados a nada con él». Se insistió en el papel de los jóvenes como «doble vanguardia del proletariado»: la juventud socialista consideraba que cada generación «tiene asignado en la historia un papel»y que el de la «nueva generación» española, precisamente por ser joven, «es el de ser la vanguardia de la revolución» ${ }^{46}$. Este proceso llevó a la Federación de Juventudes Socialistas de ser una organización totalmente dependiente del PSOE a convertirse en un movimiento cada vez más autónomo y con un claro carácter generacional, elaborando un programa de reivindicaciones puramente juveniles, que alcanzó su máxima concreción en el congreso de $1932^{47}$. La FJS se convirtió en la punta de lanza, tanto en los aspectos teóricos como en los prácticos, de la radicalización que se produjo en el movimiento socialista español en este periodo, que se vio acelerada con la salida del PSOE del gobierno, la derrota electoral de noviembre de 1933 y la extensión de los movimientos fascistas en Europa, y que la llevaron a defender una acción revolucionaria de masas. Para la juventud socialista, no sólo las posibilidades de reforma eran limitadas en una democracia burguesa, sino que ésta última conducía inevitablemente al fascismo ${ }^{48}$.

Por otra parte, aunque la proclamación del régimen republicano había significado un triunfo particular para la FUE, ensalzada como una de las parteras del nuevo régimen, pronto comenzó el declive de su hegemonía en la Universidad. La organización estudiantil perdió afiliados a medida que la crisis económica mermaba las posibilidades de promoción de los jóvenes de clase media, y

46 La cita, en Renovación, 11/11/1933, pp. 1 y 3.

47 Ya en el congreso de 1929, la FJS había aprobado un primer programa que incluía algunas reivindicaciones puramente juveniles y la organización juvenil socialista plantearía por primera vez sus demandas al nuevo régimen republicano a través de un manifiesto elaborado por su ejecutiva con motivo del primero de mayo de 1931. Renovación, 20/5/1929, p. 5 y 30/4/1931, p. 1. FEDERACiÓn NACIONAL DE Juventudes Socialistas: Resoluciones del IV Congreso, Madrid, 1932, p. 11). La evolución de los programas de las organizaciones juveniles obreras se estudia en SOUTO KUSTRÍN, Sandra: «Entre el Parlamento y la calle: políticas gubernamentales y organizaciones juveniles en la Segunda República», en Ayer (Madrid), no. 59-3 (2005), pp. 97-122, pp. 101 y ss.

48 El papel de la FJS en la radicalización socialista y en la conflictividad del periodo republicano se puede ver en SOUTO KuSTRíN, Sandra: «Taking the Streets. Workers' youth organizations and conflicts in the Spanish Second Republic», en European History Quarterly (Londres), vol. $34, n^{\circ} .2$ (abril 2004), pp. 131-156 e «Y ¿Madrid? ¿Qué hace Madrid?" Movimiento revolucionario y acción colectiva (1933-1936), Madrid, 2004, passim. 
la oficialización de la FUE por el régimen republicano dio lugar a numerosos ataques desde otras organizaciones estudiantiles, como la AET y el SEU, que le disputaron su control de la universidad. Los incidentes violentos fueron frecuentes, y se complicaban porque las asociaciones de estudiantes agrupaban también a alumnos de enseñanza media: en locales de la FUE, en institutos de educación secundaria y en facultades de distintas universidades se produjeron enfrentamientos en este período ${ }^{49}$. También fueron comunes los choques entre grupos excursionistas de organizaciones juveniles obreras con miembros de juventudes derechistas (en especial con la «Primera Línea» de Falange) o con las fuerzas de orden público. Un ejemplo de esto son los diversos enfrentamientos que se sucedieron en Madrid el 10 de junio de 1934, que produjeron varios muertos y heridos y llevaron al Ministerio de Gobernación a prohibir los grupos con insignias, banderas, y emblemas; a establecer cacheos, principalmente los días festivos, en las salidas de Madrid; y fijar multas para las organizaciones que realizasen estos actos. Finalmente, en agosto de 1934 el gobierno republicano prohibió por decreto la militancia política a menores de 16 años y a los que tuvieran menos de 23 sin el consentimiento de sus padres ${ }^{50}$.

Pero las organizaciones juveniles obreras, a pesar de su creciente actividad política, no dejarían de lado su tradicional vocación de «escuelas de la juventud». Ya en diciembre de 1930, Renovación había planteado la necesidad de compaginar ambas actividades, y los estatutos mantenidos por la federación juvenil socialista durante la Segunda República seguirían destacando los aspectos culturales y educativos, además del fomento de las actividades deportivas entre los trabajadores, que estarían incluidos en un lugar importante entre sus objetivos. Estas actividades se pueden considerar precedentes de la importante labor educativa realizada tanto por la JSU como por la FIJL durante la guerra civilis ${ }^{5}$.

La visión común del «peligro fascista» y el enfrentamiento con miembros de la Falange y otras organizaciones de derecha acercaron a las organizaciones juveniles obreras. En julio de 1934 se reunieron una delegación de la UJCE y

49 Ruiz CARnicer, Miguel Angel: «Estudiantes, cultura y violencia política en las universidades españoles (1925-1975)», en MUÑOZ, Javier, LEDESMA, José Luis, y RoDRIGO, Javier (coord.): Culturas y políticas de la violencia. España en el siglo XX, Madrid, 2005. CASTERÁs ARCHIDONA, Ramón: Diccionario de organizaciones políticas juveniles durante la Segunda República, La Laguna, 1974, p. 94. En un congreso celebrado en Sevilla en marzo de 1934 la FUE se declaró antifascista (MANCEBO, María Fernanda: «Una élite estudiantil: los primeros congresos de la Unión de Estudiantes Hispanos (UFEH)», en Les élites espagnoles à l'époque contemporaine», Pau, 1982, pp. 362-393.

50 El Socialista y El Sol, 12/6/1934, 2 , El Sol, 29/8/1934, p. 4. En la década de los treinta el grupo de edad mayoritario en España era el de los 15-24 años (López SANTAMARÍA, Jesús: «Les joventuts llibertaries durant la guerra civil», en UCELAY DA CAL, Enric (Dir): La joventut a Catalunya..., op. cit., vol. 1, pp. 152-167, p. 153).

51 Renovación, 10/12/1930, p. 3; FEDERACIÓn NACIONAL DE JUVENTUDES Socialistas: Estatutos, Madrid, Gráfica Socialista, 1932, pp. 1-3 y 19-20. FERnÁNDEZ SORIA, Juan Manuel: Juventud, ideología y educación: el compromiso educativo de las Juventudes Socialistas Unificadas, Valencia, 1992; y Cultura y libertad: la educación en las Juventudes Libertarias (1936-1939), Valencia, 1996. 
otra de la FJS. En este debate se reflejan las importantes diferencias que en cuanto a la definición de la situación, estrategias, tácticas y objetivos había entre las dos organizaciones juveniles. No hubo acuerdo sobre los objetivos que debía tener el frente único; su misma composición; el papel de las luchas parciales, o cual debía ser el órgano dirigente de la revolución. En todos estos aspectos, la posición de la FJS en estos momentos era más cercana a la de las pequeñas organizaciones juveniles del Bloc Obrer i Camperol y la Izquierda Comunista de España (ICE), con las que se relacionaba a través de la Alianza Obrera, mientras que la UJCE colaboraba con organizaciones juveniles republicanas, con las que había formado en en 1933 el Frente Juvenil Antifascista. Pero el mayor acercamiento en la actuación cotidiana en este periodo se produjo entre la FJS y la UJCE ${ }^{52}$.

La juventud desempeñó también un papel fundamental en la organización y desarrollo de la insurrección de octubre de 1934, como destacaron incluso varios dirigentes políticos de la época. La misma formación de las milicias socialistas que actuaron en octubre de 1934 no hubiera sido posible sin la participación de las juventudes. Renovación, el órgano de prensa de la organización juvenil socialista, asumió el papel de canal de información con relación a la organización de las milicias y de la insurrección. Las Milicias Socialistas que actuaron en Madrid estaban también formadas principalmente por jóvenes, fueron jóvenes los que participaron en las acciones violentas más importantes y la escasa coordinación y dirección que hubo en Madrid fue obra de los dirigentes juveniles. Pero fueron también principalmente jóvenes los que llevaron a cabo la reacción social contra la movilización obrera: en Madrid, las autoridades encargaron diversos servicios de abastecimiento de hospitales, asilos y mercados a las juventudes de los diferentes partidos de derecha y centro-derecha, que durante los días de huelga prestaron servicios en tranvías, transporte y aprovisionamiento de mercancías, o en la fabricación de pan y en la venta de los periódicos que se publicaron durante esos días ${ }^{53}$.

La participación conjunta en la movilización de octubre de 1934 de militantes de las diferentes organizaciones juveniles obreras y la gran represión posterior, que reunió a muchos de sus dirigentes en la cárcel y acercó a las organizaciones de base en la lucha conjunta por la amnistía de los presos políticos, entre otros factores, aceleraron el acercamiento entre la UJCE y la FJS, que establecieron, desde noviembre de dicho año, un comité nacional y comités provinciales de enlace entre ellas. Mientras tanto, en enero de 1935 se inició la ruptura entre la FJS y los grupos juveniles comunistas disidentes. Así, las juventudes de la ICE y

52 Renovación, 28/7/1934, pp. 1, 3 y 4; 4/8/1934, pp. 3-4; 11/8/1934, p. 3 y 18/8/1934, p. 2; y Mundo Obrero, 27/7/1934, pp. 2-3; 1/8/1934, p. 3 y 2/8/1934, p. 3.

53 SAlazar Alonso, Rafael: Bajo el signo de la revolución, Madrid, 1935, p. 227; AraQUISTAIN, Luis: «La revolución española de Octubre», en VV. AA., La revolución española de Octubre, Santiago (Chile), 1935, pp. 19-20. SOuto Kustrín, Sandra: «Y ¿Madrid? ¿Qué hace Madrid?...», op. cit., pp. 169-287. 
del BOC iniciaron un proceso paralelo de unificación que dio lugar a la Juventud Comunista Ibérica (JCI), como organización juvenil del Partido Obrero de Unificación Marxista (POUM), en septiembre de 1935, que centraba su fuerza principalmente en Cataluña y que llegó a tener a principios de 1937 unos 10.000 afiliados. A pesar de que las relaciones entre la FJS y la UJCE pasaron por numerosos altibajos, la actividad propagandística - fundamentalmente clandestina - realizada de forma conjunta entre ambas organizaciones tanto en el ámbito nacional como en los ámbitos locales fue importante, e incluyó tanto temas relativos a la represión posterior a octubre de 1934, como cuestiones más generales, como las concentraciones de las JAP o la ocupación de Abisinia por Italia, aunque las direcciones del PSOE y de su sindicato recomendaron no hacerlo. Joven Guardia, órgano de la UJCE, destacó que muchos trabajos de propaganda se habían hecho, "desde un comienzo», «sobre la base del frente único con los jóvenes socialistas» ${ }^{54}$. Pero a pesar de la importancia de los jóvenes en la movilización a favor de la amnistía durante todo el año de 1935, el papel de las organizaciones juveniles en el proceso de formación del Frente Popular, o en la configuración de las diferentes candidaturas que se presentaron a las elecciones de febrero de 1936, fue bastante escaso, aunque los responsables de las principales organizaciones juveniles formaron parte de las listas electorales. Sí fue, en cambio, importante su participación en la campaña electoral, como destacó, por ejemplo, Mundo Obrero, el periódico del PCE ${ }^{55}$.

La convergencia de la UJCE con la FJS llevaría en la primavera de 1936 a la fusión de ambas organizaciones en las Juventudes Socialistas Unificadas (JSU), favorecida por la política frentepopulista establecida por el VII Congreso de la Internacional Comunista, celebrado en julio-agosto de 1935, y el VI de la Internacional Juvenil Comunista, celebrado en septiembre de dicho año. Esto llevaría a la creación de una «organización juvenil de nuevo tipo», abierta a jóvenes de diferentes ideologías, independiente, y que mantendría relaciones con todos los partidos que formaban el Frente Popular, sin depender teóricamente de ninguno de ellos ${ }^{56}$. Este proceso de convergencia convirtió a la organización juvenil socialista unificada en el grupo juvenil organizado más impor-

54 Acta de la reunión de 1 de noviembre entre la FJS y la UJCE, Fundación Pablo Iglesias, Archivos varios, CV-18. En esta reunión la FJS planteó por primera vez la unificación de ambas organizaciones. Boletín Interior de la JCE-ICE, 25/4/1935, pp. 11-13; CASTERÁs, Ramón: «Las Juventudes Comunistas Ibéricas del POUM», en Studia Historica. Historia Contemporánea (Salamanca), vol. V, no 4 (1987), p. 71; Joven Guardia, 6/1935, p. 7. La FJS y la UJCE intentaron que la FIJL participara en una campaña conjunta por la amnistía, pero las federaciones provinciales de ésta lo rechazaron (AHN, ATM (Cr.), leg. 1/1, nº. 20, 174/35 y leg. 230/1, nº. 6, 274/35). La represión afectó también a la FUE, que vio sus locales cerrados y perdió su carácter oficial.

55 Mundo Obrero, 15/2/1936, p. 4 y 20/2/1936, p. 4.

56 WOLFF, Michael, "Unamos las fuerzas de la nueva generación». Informe presentado al VI Congreso de la Internacional Juvenil Comunista, Bilbao, s.f., pp. 18 y ss. El proceso de formación de la JSU se puede seguir en VIÑAS, Ricard La formación de las Juventudes Socialistas Unificadas (1934-1936), Madrid, 1978, aunque el autor no contaba con la importante reunión de 1 de noviembre de 1934. 
tante del momento. También se inició en la primavera de 1936, el proceso de convergencia de la JSU con otras organizaciones juveniles (especialmente con las de los partidos republicanos y con la FUE), con la formación del Frente de la Juventud, base de la política de alianzas de la JSU durante la guerra civil ${ }^{57}$.

Los grupos estudiantiles vinculados a la extrema derecha trataron de contrarrestar, tras las elecciones de febrero de 1936, el proceso de convergencia iniciado por las juventudes obreras: el SEU, la AET, la católica CECE-AEC y las Juventudes Universitarias del partido monárquico Renovación Española se embarcaron en un proyecto de Frente Nacional Universitario que se frustró por la negativa de los católicos a diluirse en un organismo único, y por la inmersión de Falange en una espiral terrorista y la detención de sus principales dirigentes en marzo de $1936^{58}$.

\section{EPÍlOGO: LA GUERRA CiVIL, ¿UNA MOVILIZACIÓN JUVENIL?}

Durante la guerra civil ambos bandos ensalzaron el espíritu de sacrificio que mostraban unos combatientes identificados con los estereotipos del idealismo, el dinamismo y la generosidad de la juventud. Ésta jugó un papel muy importante en el esfuerzo de guerra republicano, y de movilizarla se encargarían principalmente la Juventud Socialista Unificada y la Federación Ibérica de Juventudes Libertarias, las organizaciones juveniles que más crecieron durante la guerra: la JSU hablaría en su Conferencia Nacional de la Juventud, celebrada en Valencia en enero de 1937, de 300.000 afiliados, mientras que la FIJL decía tener entre 130.000 y 150000 afiliados en mayo de 193759 .

57 El Frente de la Juventud tuvo su origen en la convocatoria por parte de la Federación Internacional de Asociaciones por la Sociedad de Naciones de un Congreso Mundial de la Juventud, que se celebró en Ginebra en agosto de 1936, y para el que se organizó una primera reunión preparatoria en Bruselas en febrero de 1936, que hizo que se empezaran a coordinar las entidades españolas que se adhirieron al congreso (ver Mundo Obrero, 26/2/36, p. 4 y 21/4/36, p. 4; y Youth Plans a New World. Being the Official Record of the First World Youth Congress, Geneva 31.viii-6.ix 1936, Organised by the International Federation of League of Nations Societies, Ginebra, 1937 (2a . ed.). Juventud. Diario de la Juventud en Armas, 28/10/1936, p. 4, incluye entre los componentes del Frente de la Juventud, entre otras organizaciones, a las Juventudes de Izquierda Republicana (JIR), las de Unión Republicana (JUR), las de Izquierda Federal (JIF); la Juventud de Izquierda Radical Socialista, Agrupación de Mujeres Republicanas de Izquierda, Unión Republicana Femenina, Agrupación de Mujeres Antifascistas, la Federación Cultural Deportiva Obrera, «Salud y Cultura», la Federación de Trabajadores de la Enseñanza y la Unión Federal de Estudiantes Hispanos (UFEH).

58 «Hacia la sindicación única», Haz, no 14, 14/2/1936, p. 6, cit. en IBÁÑEZ HERNÁNDEZ, Rafael: Estudio y acción. La Falange fundacional a la luz del diario de Alejandro Salazar, Madrid, 1993, pp. 231-232.

59 Archivo General de la Guerra Civil Española (AGGC), Sección Político-Social (PS) Extremadura 3, expte. 7, Actas de la Conferencia Nacional de la Juventud, p. 32; López SANTAMARÍA, Jesús: «Juventudes Libertarias y guerra civil (1936-1939)», en Studia Histórica. Época Contemporánea (Salamanca), vol. 1, no. 4 (1983), pp. 215-222, p. 222. 
Aunque esta participación juvenil ha sido destacada por muy pocos historiadores, como dice Helen Graham, los informes de la Comandancia de Milicias muestran que «el reclutamiento, lejos de derivar del "pueblo en armas» como un todo o del proletariado organizado, provenía principalmente de sectores de hombres jóvenes, no cualificados y previamente no movilizados» ${ }^{60}$. De la importancia de los jóvenes en el esfuerzo bélico republicano eran muy conscientes las organizaciones juveniles, que reivindicaron el papel de los jóvenes en el fracaso del golpe de Estado de julio de 1936; e insistieron en la importancia de la juventud en el Ejército republicano y en la dirección de la guerra. Ya el 22 de octubre de 1936, se incluyeron diez dirigentes de la JSU en el Estado Mayor de Guerra y esta organización juvenil planteó en su conferencia de 1937 que de sus 300.000 afiliados, 150.000 eran miembros del Ejército ${ }^{61}$. Fue también de la JSU de la que partió la iniciativa de la educación premilitar de los jóvenes de entre 14 y 20 años, a través del llamado movimiento iAlerta!, con la idea de prepararlos para su incorporación al Ejército ${ }^{62}$.

Por otra parte, continuó en la zona republicana el proceso de unificación juvenil iniciado en 1934. El Frente de la Juventud redujo su composición inicial a las organizaciones expresamente juveniles (JSU, UFEH, juventudes republicanas y Juventudes Sindicalistas) y la JSU defendió la creación, a partir de él, de una Alianza Nacional de la Juventud ${ }^{63}$, que pasó a denominar Alianza Juvenil Antifascista para acercar posiciones con los jóvenes libertarios. En un primer momento, esta estrategia se encontró con la oposición de la FIJL y de la JCI, que defendían la formación de un Frente de la Juventud Revolucionario, que se creó en Cataluña en febrero de 1937, reflejando la división en el seno de las fuerzas obreras españolas sobre las prioridades en la nueva situación: ganar la guerra o hacer una revolución. Los sucesos de mayo de 1937 en Barcelona llevaron a la ruptura por parte de la FIJL del Frente de la Juventud Revolucionario y favorecieron el acercamiento de la organización juvenil anarcosindicalista a la JSU, que llevó a la formación, en agosto de 1937, de la Alianza Juvenil Antifascista (AJA), entre la JSU, la FIJL, las Juventudes Sindicalistas y las diferentes organizaciones juveniles republicanas ${ }^{64}$.

60 Graham, Helen: The Spanish Republic at War, Cambridge, 2002, p. 176 (edición en castellano: La República en guerra, 1936-1939, Madrid, 2006).

61 Véase Juventud, órgano de la JSU, 28/10/1936, 4; Tierra y Libertad, 8/1936, reproducido en UCElay DA CAL, Enric (dir.): La joventut a Catalunya..., op. cit., vol. 2, p. 175; u Octubre, órgano de la JSU, 5/9/1936, p. 1. AGGC, PS Extremadura 3, expte. 7, Actas de la Conferencia Nacional de la Juventud, p. 1; MuÑoz ArConAda, Felipe: La juventud en la defensa de Madrid, Madrid, [1937], p. 19.

62 Ahora, diario de la JSU, 8/1/37, pp. 4-5; MUÑOZ ARCONADA, Felipe: La juventud en la defensa..., op. cit., pp. 20-21.

63 Ahora, 16/12/1937, p. 3; JuventUdes Socialistas UNIFICADAS: La JSU dice a toda la Juventud laboriosa. iPor la Alianza Nacional de la Juventud!, Madrid, s.f. [marzo de 1937].

64 Ahora, 8/1/1937, 4-5; Dictamen del pleno de la FIJL de 1 de febrero de 1937 reproducido en Cabañas, José: Frente de la Juventud...? Madrid, s.f., pp. 9-12. A pesar de la existencia del Fren- 
La JSU también reivindicó nuevos derechos para los jóvenes, que en su mayor parte fueron asumidas por la AJA tras su creación. Estas reivindicaciones incluían la lucha contra el analfabetismo en el campo, la igualdad de las mujeres y la implantación del subsidio de maternidad a cargo del Estado, o la concesión de derechos sindicales y políticos a los jóvenes a partir de los 18 años, y que estos derechos los tuvieran también los soldados. ${ }^{65}$ Defendió además, en el contexto de los importantes cambios en el papel de la mujer producidos por la guerra, una organización independiente de las mujeres jóvenes (la Unión de Muchachas) justificándola en el papel decisivo que jugaban en la producción al estar los hombres en el frente y en su «atraso cultural» por la educación católica que habían recibido. La Unión de Muchachas debería ser, al igual que la JSU, una «organización de nuevo tipo», abierta a todas las jóvenes fueran afiliadas a cualquiera de las organizaciones antifascistas o no militantes. Aunque los intentos de la JSU de vincular esta organización a la Alianza Juvenil Antifascista (AJA), fracasaron, la Unión de Muchachas jugó un papel importante en la movilización de las jóvenes sin partido y católicas en la retaguardia, como ejemplifica la evolución y la militancia de las 13 Rosas $^{66}$.

te de la Juventud Revolucionaria, la creación de la Alianza Juvenil Antifascista en España fue precedida de acuerdos locales o provinciales, como los de Madrid, Murcia o Ciudad Real, aunque es difícil saber si seguían existiendo cuando se creó la AJA en el ámbito nacional (Ver, por ejemplo, Ofensiva, $13 / 3 / 1937$, sin paginar; Abora, 20/3/1937, p. 8; $27 / 3 / 1937$, p. 10; 7/4/1937, p. 10 ; o $15 / 4 / 1937$, p. 9). La disolución del Frente de la Juventud Revolucionario se recoge en Ahora, 30/5/1937, p. 4. En diciembre de 1937, el Frente de la Juventud se disolvería formalmente (Abora, 16/12/1937, p. 3). Sólo en Cataluña la AJA no se creó hasta abril de 1938 (CASTERÁs ARCHIDONA, Ramón: Diccionario de organizaciones..., op. cit., p. 20). El proceso de convergencia entre las organizaciones obreras hizo que también las juventudes republicanas se plantearan su unificación, pero ésta no se llegó a realizar (AGGC, PS Madrid, 1743, proyecto orgánico para la unificación de las juventudes republicanas).

${ }_{65}$ Desde sus orígenes, la FJS se preocupó por la situación de la mujer y las reivindicaciones de los derechos de la mujer llegaron a ser una parte importante de sus programas (GONZÁLEZ QUINTANA, Antonio: «La primera organización de jóvenes proletarios...», op. cit., p. 33; Renovación, 20/5/1929, «El tercer Congreso Nacional de las Juventudes Socialistas», p. 5). JuvENTUDES SoCIALISTAS UNIFICADAS, Las diez reivindicaciones de la juventud, Valencia, s. f. [1937]. La FJS había reivindicado desde la proclamación de la República el derecho de voto a partir de los 21 años, frente a los 23 establecidos por la Constitución de 1931 (ver, por ejemplo, Renovación, 10/5/1931, p. 3 у 10/10/1931, p. 1; y FEDERACIÓN NACIONAL DE LAS JUVENTUDES SOCIALISTAS, Estatutos, op. cit., p. 5). La ley de asociaciones republicana de 8 de abril de 1932 exigía ser mayor de 21 años para poder formar parte de las direcciones de los sindicatos (ver MARTín VALVERDE, Antonio et alii: La legislación social..., op. cit., p. 739).

66 Juventudes Socialistas Unificadas: Por la organización de las muchachas, Madrid, s.f. Véase también AGGC, PS Extremadura 3, expte. 7, Actas de la Conferencia Nacional de la Juventud, p. 14, «Informe de la camarada Antonia sobre el trabajo de las mujeres». FONSECA, Carlos: Trece rosas rojas, Madrid, 2004, pp. 25-91. En mayo de 1937 se celebró un Congreso de Muchachas organizado por la JSU, la JUR y la JIR en que se decidió crear una nueva organización de masas de las mujeres jóvenes «que no será el apéndice de ninguna otra, pero que tendrá en todas las organizaciones juveniles los más firmes apoyos» y que centraría sus actividades en la educación de las jóvenes y la organización de actividades de mantenimiento de la retaguardia (Ofensiva, 28/5/1937, sin paginar). 
El papel real de la AJA es muy difícil de valorar: asumió el movimiento iAlerta! y las brigadas de choque, llamadas ahora brigadas de superproducción $^{67}$, pero las juventudes republicanas eran escasas en número, y los recelos mutuos entre la FIJL y la JSU no desaparecieron. Por el contrario, la desconfianza de la primera se acrecentó con la propuesta de la segunda de crear una organización única de la juventud, considerada por las juventudes anarcosindicalistas como un simple intento de absorción. Cuando apenas hacía un año de la creación de la AJA, desde las Juventudes Libertarias se decía que sus bases no significaban «nada más que el acuerdo platónico de la juventud» y se la definía como «un cuerpo muerto» ${ }^{68}$. Las difíciles condiciones provocadas por el embargo internacional, la desagregación de la zona republicana y la marcha negativa de la guerra también consumió a las organizaciones juveniles, divididas en el colapso final de la República. Por ejemplo, en el otoño de 1938 los enfrentamientos entre la «vieja guardia» socialista de la JSU, de tendencia caballerista en su mayor parte, y su dirección comunista alcanzarían «dimensiones de guerra civil interna», llegando a producirse enfrentamientos violentos entre partidarios de los dos sectores y, en los días de enfrentamiento que siguieron al golpe de Estado del coronel Casado, los jóvenes caballeristas atacarían las sedes de la JSU en diferentes ciudades republicanas ${ }^{69}$.

También en el bando franquista se diría que la acción de los sublevados había sido una «empresa de la juventud»: «ya cuando la Falange cuajaba (...) los jóvenes eran los viriles y aguerridos paladines del ideal» y «cuando sonó la hora suprema de la guerra, con qué encendido entusiasmo se lanzaron los jóvenes falangistas a la lucha abierta», aunque se reconocía también que «en las retaguardias rojas» hubo «admirables ejemplos de abnegación y de heroísmo en los jóvenes afiliados». Pero la estructura claramente jerarquizada y militarizada del poder que se fue organizando desde el comienzo de la sublevación no permitió que la juventud asumiera un papel tan destacado como en la zona republicana, aunque numerosos jóvenes actuaron en la quinta columna y al terminar la guerra muchos ocuparon lugares de mando, «sino importantes, si por lo

67 Véase AGGC, PS Madrid 1121, Circular no. 9 (4/9/1937) y n ${ }^{\circ} .11$ (9/9/1937) del CP de la FIJL; informe de la FIJL sobre la AJA de 23 de septiembre de 1937 (AGGC, PS Madrid 1191, leg. 4154, expte. 4); y Ahora, 10/9/1937, p. 2. Boletín de la Federación Nacional de las J. S. U., nº. 2, febrero de 1938, «Resolución aprobada por el Consejo Nacional de la Alianza Juvenil Antifascista y por las Direcciones Nacionales de las Organizaciones participantes de la misma, en reunión conjunta celebrada en Barcelona los días 22 y 23 de enero de 1938», pp. 1-10. Ver también Ahora, 4/2/1938, p. 3 .

68 Ahora, 4/8/1938, p. 1; Buitrago, Amor: Significado y fundamento de la unidad juvenil. Conferencia pronunciada en el cine Proyecciones, octubre de 1938, s.l., 1938, pp. 16, 18 y 30; informes de la FIJL sobre la situación de la AJA de mayo y septiembre de 1938 conservados en AGGC, PS Madrid 1191.

69 González Quintana, Antonio y Martín Nájera, Aurelio: Apuntes para la Historia de las Juventudes Socialistas de España, Madrid, 1983, p. 63; GrAHAM, Helen: El PSOE en la Guerra Civil. Poder, crisis y derrota (1936-1939), Barcelona, 2005, pp. 277-287 y 296-297, la cita en p. 277. 
menos de cierta influencia». Esto explicaría que un intelectual joven como Dionisio Ridruejo reivindicase en 1940 el poder para su generación, por ser aquella que no sólo había hecho la guerra, sino que además, «la había provocado, entendido en sus más profundas razones y encarnado en toda su dimensión revolucionaria». Sin embargo, el Estado franquista desarticuló sistemáticamente las formaciones juveniles de izquierda con el decreto de 13 de septiembre de 1936 que declaraba ilegales todas las organizaciones políticas del Frente Popular; mientras que la unidad de los partidos de derecha y de sus organizaciones anejas fue forzada por el Decreto de Unificación de 19 de abril de 1937, que dio lugar a la creación de Falange Española Tradicionalista y de las JONS, cuyos estatutos designaban a la Organización Juvenil como uno de los Servicios Nacionales del nuevo partido único. El SEU, la AET y otras agrupaciones estudiantiles de derecha fueron oficialmente integradas en un SEU unificado el 12 de octubre de 1937. Por último, la ley fundadora del Frente de Juventudes, de 6 de diciembre de 1940, fue el paso final que condujo a la burocratización y estatalización de la juventud española ${ }^{70}$. De este modo, se clausuraba oficialmente la vigorosa corriente de emancipación y de implicación extrema en la vida política que había sido característica de la juventud española durante la década anterior.

70 Manegat, Luis G.: Muy Falangista, Barcelona, 1940, reproducido en Ucelay Da CaL, Enric (dir.): La joventut a Catalunya..., op. cit., vol. 2, pp. 201-203, la primera cita en p. 201, las demás, en p. 203. AlBA, Victor: Historia Social de la Juventud, Barcelona, 1979, p. 190. Se ve el papel importante de los jóvenes en la quinta columna madrileña, aunque el autor no lo destaca, en CERVERA, Javier: Madrid en guerra. La ciudad clandestina, 1936-1939, Madrid, 1998. La cita de Ridruejo en Arriba, 5/5/1940, está reproducida en SAZ CAMPOS, Ismael: España contra España. Los nacionalismos franquistas, Madrid, 2003, p. 300. El proceso de organización desde arriba de la juventud bajo la dictadura franquista se analiza en SÁEz MARíN, Juan: El Frente de Juventudes. Política de juventud en la España de la postguerra (1937-1960), Madrid, 1988. 